\title{
Genetic Diversity Analysis of Date Palm (Phoenix dactylifera L.) Cultivars from Morocco Using SSR Markers
}

\author{
Amy Bodian ${ }^{1^{*}}$, Marion Nachtigall ${ }^{2}$, Lothar Frese ${ }^{2}$, Mohammed Aziz Elhoumaizi ${ }^{3}$, Amina Hasnaoui $^{3}$, Khadidiatou Ndoye Ndir ${ }^{4}$ and Djibril Sané $^{1}$ \\ ${ }^{1}$ Department of Plant Biology, Faculty of Sciences and Technology University Cheikh Anta Diop of Dakar, BP 5005, Senegal
}

2Julius Kühn-Institut, Federal Research Centre for Cultivated Plants, Institute for Breeding Research on Agricultural Crops, Erwin-Baur-Str. 27, 06484 Quedlinburg, Germany

${ }^{3}$ Department of Biology, Faculty of Sciences University Mohammed $1^{\text {st }}$ Oujda, Morocco

${ }^{4}$ Department of Crop Sciences, UFR Agronomic Sciences and Rural Development University of Thiès, Senegal

"Corresponding author: Amy Bodian, Department of Plant Biology, Faculty of Sciences and Technology University Cheikh Anta Diop of Dakar, BP 5005 Senegal, Tel: +221 3382504 43; Fax: 2213382463 18; E-mail: miamybo@yahoo.fr ; ami.bodian@ceraas.org

Received date: Aug 26, 2014, Accepted date: Sep 27, 2014, Publication date: Sep 29, 2014

Copyright: (c) 2014 Bodian A, et al. This is an open-access article distributed under the terms of the Creative Commons Attribution License, which permits unrestricted use, distribution, and reproduction in any medium, provided the original author and source are credited.

\begin{abstract}
In Morocco, date palm is the most important arboricultural crop and little is known about its germplasm. Thus, this work aimed at analyzing genetic diversity among 200 date palms sampled from three oases (Figuig, Tata and Zagora) of Morocco using microsatellite markers. Among these palms, 191 were females, belonging to 26 cultivars, and 9 were males. Eighteen primers were used for the analysis of their genetic diversity. Only 15 primers amplified successfully all the samples. The total number of alleles was 116 and the percentage of polymorphic loci was high and ranged between 60 and $100 \%$ with an average of $93.33 \%$. The genetic similarity values ranged from 0.146 to 0.745 . The molecular variance analysis showed $64 \%$ of variability among cultivars. The obtained dendrogram showed three groups and generally, a good structuring of cultivars. However, we noticed one case of homonymy among cultivars. In fact "Tadmant" cultivar of Figuig was different from "Tadmant" of Tata and Zagora. Males were clustered in two main subgroups.
\end{abstract}

Keywords: Cultivars; Phoenix dactylifera; Genetic diversity; Microsatellite markers; Morocco

\section{Introduction}

Date palm (Phoenix dactylifera L.) is a dioecious perennial monocotyledon plant with long generation times (a period of 4 to 5 years is necessary to reach the first flowering) that belongs to Arecaceae family [1]. It is a diploid $(2 n=2 x=36)$, and the predicted genome size is estimated to be approximately between 550 and 650 Mbp [2]. Date palm has traditionally been vegetatively propagated from offshoots produced by elite individual trees. In Morocco, more than 220 clonally propagated varieties are known [3] and date palm is the most important arboricultural crop. There are 4.7 million palm trees covering a surface area of approximately 44,000 ha. More than 220 clonally propagated varieties are known [3]. All commercial varieties are female and there is no method yet of producing male palms of these varieties. However, the effects of pollen on date quality through metaxenia are well documented, and male genotypes with desirable qualities are maintained in the plantations and commonly used to hand pollinate female trees.

The most serious fungal disease threatening date palm plantations in North Africa, especially in Morocco is "Bayoud" [4]. This vascular wilt caused by Fusarium oxysporum $f$. sp. albedinis has recently affected about $67 \%$ of Moroccan palm trees and has continued to spread to the East, demolishing a large portion of the palm groves in its path. This disease has destroyed more than 12 million palms in Morocco [5].
Despite all these problems, little is known about Moroccan date palm genetic diversity and resistance of different cultivars to Bayoud.

Date palm varieties can be differentiated using morphological markers viz., shape, size, weight, color, aspects of fruit skin, consistency, texture, etc. [6,7] and biochemical markers like isozymes and proteins $[8-10]$ but these traits are greatly influenced by environmental factors as well as the developmental stages of the plant. The random amplified polymorphic DNA (RAPD), amplified fragment length polymorphism (AFLP), inter simple sequence repeats (ISSR), random amplified microsatellite polymorphism (RAMPO) and microsatellites (SSR) have earlier been employed for germplasm characterization of different date palm cultivars from Saudi Arabia and other countries like Qatar, Egypt, Tunisia, Sudan, Mauritania and Morocco with similar climatic conditions [11-24]. In most of these studies, considerable genetic diversity has been detected in date palm germplasm.

Microsatellites or SSR (simple sequence repeats) or STR (short tandem repeats) are repeating sequences of 2 to 6 nucleotides in noncoding regions generally [25]. They are distributed in all regions of the genome [26-29] and are present in all eukaryotes [30,31] and in some prokaryotes [32] and are evenly spread across the genome [26-29]. Microsatellites are preferential markers used in the study of genetic diversity because they are abundant [33,34], typically co-dominant and of a high variability [35]. The objective of this work is therefore to analyze the genetic diversity of common cultivars of three date palm oases from Morocco using SSR markers. 
Citation: Bodian A, Nachtigall M, Frese L, Aziz Elhoumaizi M, Hasnaoui A, et al. (2014) Genetic Diversity Analysis of Date Palm (Phoenix dactylifera L.) Cultivars from Morocco Using SSR Markers. J Biodivers Biopros Dev 1: 126. doi:10.4172/2376-0214.1000126

Page 2 of 8

\section{Materials and Methods}

\section{Study area}

Samples were collected in three oases (Figuig, Tata and Zagora) (Figure 1). Figuig is situated in North East Morocco (latitude: $32^{\circ} 07^{\prime} 1^{\prime \prime}$ N, longitude: $1^{\circ} 13^{\prime} 37^{\prime \prime} \mathrm{W}$, altitude: $903 \mathrm{~m}$ ); Tata is in North West Morocco (latitude: $29^{\circ} 44^{\prime} 34^{\prime \prime} \mathrm{N}$, longitude: $7^{\circ} 58^{\prime} 21^{\prime \prime} \mathrm{W}$, altitude: 670 $\mathrm{m}$ ) and Zagora is in South East Morocco (latitude: $30^{\circ} 19^{\prime} 56^{\prime \prime}$ Nord, longitude: $5^{\circ} 50^{\prime} 18^{\prime \prime}$ Ouest, altitude: $698 \mathrm{~m}$ ).

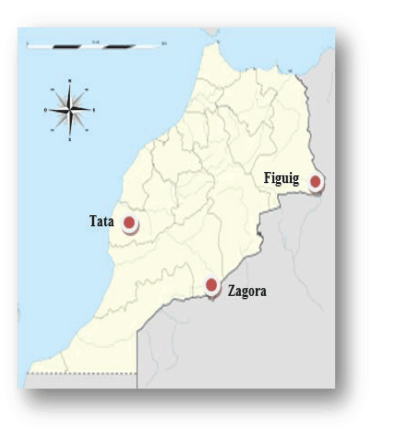

Figure 1: Representation of Figuig, Tata and Zagora oases on Morocco map.

\section{Plant material}

A set of 200 date palm samples were used in this study (Table 1). They consisted of 26 female cultivars and 9 males from 3 Moroccan oases. In Figuig oasis, 128 samples (121 belonged to 11 cultivars and 7 males) were collected; in Tata, 20 samples ( 18 belonged to 9 cultivars and 2 males) and in Zagora, 52 samples (belonging to 10 cultivars). Cultivars were the most common genotypes in these oases while males were less frequent as they only serve as pollinators. Young leaves of adult trees were dried and conserved in silicagel.

\begin{tabular}{|l|l|l|}
\hline Oases & cultivars & Number of samples \\
\hline & Afroukh n'tijent & 10 \\
\hline & Admam & 4 \\
\hline & Aziza bouzid & 15 \\
\hline & Aziza manzou & 15 \\
\hline Figuig & Assiane & 17 \\
\hline & Boufeggous & 16 \\
\hline & Boufeggous gharas & 11 \\
\hline & Mejhoul & 4 \\
\hline & Taâbdount & 11 \\
\hline & Tadmamt & 3 \\
\hline & Tgharas & 15 \\
\hline & $\begin{array}{l}\text { Males } \\
\text { Total }\end{array}$ & 7 \\
\hline
\end{tabular}

\begin{tabular}{|c|c|c|}
\hline & Admam & 2 \\
\hline & Amanane & 1 \\
\hline & Boufeggous & 4 \\
\hline & Bouhassa & 1 \\
\hline & Bouyatoub & 1 \\
\hline \multirow[t]{10}{*}{ Tata } & Bouskri & 2 \\
\hline & Jihel & 4 \\
\hline & Taghanimt & 1 \\
\hline & Tiguemi n'tanout & 1 \\
\hline & Sayer laalat & 1 \\
\hline & Males & 2 \\
\hline & Total & 20 \\
\hline & Ahardane & 2 \\
\hline & Aguellid & 10 \\
\hline & Boufeggous & 10 \\
\hline \multirow[t]{7}{*}{ Zagora } & Bousthammie noire & 2 \\
\hline & Bouzgagh & 2 \\
\hline & Iklane & 2 \\
\hline & Jihel & 10 \\
\hline & Meh albayd & 2 \\
\hline & Oum nehl & 2 \\
\hline & $\begin{array}{l}\text { Tadmant } \\
\text { Total }\end{array}$ & $\begin{array}{l}10 \\
52\end{array}$ \\
\hline
\end{tabular}

Table 1: List of collected date palm cultivars in different Oases.

\section{DNA isolation}

Genomic DNA was extracted using a modified preparation procedure according to Bousquet et al. [36]. After purification, DNA yields were determined by a NanoDrop 800 spectrophotometer (PEQLAB Biotechnologie $\mathrm{GmbH}$ ) and diluted to a working concentration of $25 \mathrm{ng} / \mathrm{l}$.

\section{Microsatellites amplification and electrophoresis}

A PCR was carried out using 18 date-palm SSR markers developed by Billotte et al. [37] and Akkak et al. [38] (Table 2). PCR reactions were performed in a total reaction mixture of $10 \mu \mathrm{l}$ containing: $25 \mathrm{ng}$ template DNA; $1 \mu$ of PCR buffer $10 \mathrm{X} ; 2.0 \mathrm{mM} \mathrm{MgCl} 2 ; 0.2 \mathrm{mM}$ dNTP; $0.06 \mu \mathrm{M}$ of the universal Cy5-labeled M13- primer (5'tgtaaaacgacggccagt- $\left.3^{\prime}\right) ; 0.08 \mu \mathrm{M}$ of M13-tailed forward primer at the 5 'end [39], (F); $0.1 \mu \mathrm{M}$ of reverse primer (R); $0.5 \mathrm{U}$ of Taq DNA polymerase (Tina Taq). Amplifications were performed using a $\mathrm{MJ}$ Research PTC 200 thermal cycler (Bio-Rad Laboratories Inc.) with the following cycle profile: initial denaturation for $1 \mathrm{~min}$ at $95^{\circ} \mathrm{C}$ followed by 35 cycles with $30 \mathrm{sec}$ at $94^{\circ} \mathrm{C}, 1 \mathrm{~min}$ at primer-specific annealing temperature (Table 2), $2 \mathrm{~min}$ at $72^{\circ} \mathrm{C}$ and a final extension step at $72^{\circ} \mathrm{C}$ 
Citation: Bodian A, Nachtigall M, Frese L, Aziz Elhoumaizi M, Hasnaoui A, et al. (2014) Genetic Diversity Analysis of Date Palm (Phoenix dactylifera L.) Cultivars from Morocco Using SSR Markers. J Biodivers Biopros Dev 1: 126. doi:10.4172/2376-0214.1000126

Page 3 of 8

for 8 min. All PCR products were separated on a $6 \%$ polyacrylamide denaturing gel using an automatic laser fluorescence-sequencing of PCR product diluted $4 \mathrm{X}$ in loading buffer.

\begin{tabular}{|c|c|c|c|c|}
\hline Primer names & Primer sequences & $\begin{array}{l}\text { Repeated } \\
\text { motif }\end{array}$ & $\begin{array}{l}\text { Size } \\
\text { (bp) }\end{array}$ & Annealing temperature $\left({ }^{\circ} \mathrm{C}\right)$ \\
\hline \multirow[b]{2}{*}{ MPdCIR010 } & F: ACCCCGGACGTGAGGTG & \multirow[b]{2}{*}{$(G A) 22$} & \multirow[b]{2}{*}{180} & \multirow[b]{2}{*}{55,9} \\
\hline & R: CGTCGATCTCCTCCTTTGTCTC & & & \\
\hline \multirow[b]{2}{*}{ MPdCIR015 } & F: AGCTGGCTCCTCCCTTCTTA & \multirow[b]{2}{*}{$(\mathrm{GA}) 15$} & \multirow[b]{2}{*}{253} & \multirow[b]{2}{*}{51,6} \\
\hline & R: GCTCGGTTGGACTTGTTCT & & & \\
\hline \multirow[b]{2}{*}{ MPdCIR016 } & F: AGCGGGAAATGAAAAGGTAT & \multirow[b]{2}{*}{$(\mathrm{GA}) 14$} & \multirow[b]{2}{*}{209} & \multirow[b]{2}{*}{51,7} \\
\hline & R:ATGAAAACGTGCCAAATGTC & & & \\
\hline \multirow[b]{2}{*}{ MPdCIR025 } & F:GCACGAGAAGGCTTATAGT & \multirow[b]{2}{*}{ (GA)22 } & \multirow[b]{2}{*}{269} & \multirow[b]{2}{*}{49,3} \\
\hline & R: CCCCTCATTAGGATTCTAC & & & \\
\hline \multirow[b]{2}{*}{ MPdCIR032 } & F: CAAATCTTTGCCGTGAG & \multirow[b]{2}{*}{ (GA)19 } & \multirow[b]{2}{*}{376} & \multirow[b]{2}{*}{51,5} \\
\hline & R: GGTGTGGAGTAATCATGTAGTAG & & & \\
\hline \multirow[b]{2}{*}{ MPdCIR035 } & F: ACAAACGGCGATGGGATTAC & \multirow[b]{2}{*}{$(\mathrm{GA}) 15$} & \multirow[b]{2}{*}{341} & \multirow[b]{2}{*}{53,9} \\
\hline & R: CCGCAGCTCACCTCTTCTAT & & & \\
\hline \multirow[b]{2}{*}{ MPdCIR044 } & F: ATGCGGACTACACTATTCTAC & \multirow[b]{2}{*}{$(\mathrm{GA}) 19$} & \multirow[b]{2}{*}{340} & \multirow[b]{2}{*}{51,7} \\
\hline & R: GGTGATTGACTTTCTTTGAG & & & \\
\hline \multirow[b]{2}{*}{ MPdCIR048 } & F: CGAGACCTACCTTCAACAAA & & & \\
\hline & R: CCACCAACCAAATCAAACAC & $(\mathrm{GA}) 32$ & 439 & 51,4 \\
\hline & F: CTGCCATTTCTTCTGAC & & & \\
\hline MPdCIR050 & R: CACCATGCACAAAAATG & $(\mathrm{GA}) 21$ & 568 & 48,5 \\
\hline & F: AAGCAGCAGCCCTTCCGTAG & & & \\
\hline MPdCIR057 & R: GTTCTCACTCGCCCAAAAATAC & $(\mathrm{GA}) 20$ & 360 & 55,4 \\
\hline & F: CTTTTATGTGGTCTGAGAGA & & & \\
\hline MPdCIR063 & R: TCTCTGATCTTGGGTTCTGT & $(\mathrm{GA}) 17$ & 301 & 49,8 \\
\hline & F: CAAGACCCAAGGCTAAC & & & \\
\hline MPdCIR070 & R: GGAGGTGGCTTTTGTAGTAT & (GA)17 & 265 & 48,7 \\
\hline & F: TGGATTTCCATTGTGAG & & & \\
\hline MPdCIR078 & R: CCCGAAGAGACGCTATT & (GA)13 & 260 & 49,6 \\
\hline & F: GAGAGAGGGTGGTGTTATT & & & \\
\hline MPdCIR085 & R: TTCATCCAGAACCACAGTA & $(\mathrm{GA}) 29$ & 375 & 50,4 \\
\hline & F: GCAGTCAGTCCCTCATA & & & \\
\hline MPdCIR090 & R: TGCTTGTAGCCCTTCAG & $(\mathrm{GA}) 26$ & 269 & 48,6 \\
\hline & F: CCATTTATCATTCССТСТCTTG & & & \\
\hline MPdCIR093 & R: CTTGGTAGCTGCGTTTCTTG & $(\mathrm{GA}) 16$ & 230 & 51,8 \\
\hline & F: AACCACGGGGATCTATTTGT & & & \\
\hline PdCAT01 & R: AACTTCTACTTTGCTTGCCATCA & (TC)21 & 161 & 51 \\
\hline
\end{tabular}


Citation: Bodian A, Nachtigall M, Frese L, Aziz Elhoumaizi M, Hasnaoui A, et al. (2014) Genetic Diversity Analysis of Date Palm (Phoenix dactylifera L.) Cultivars from Morocco Using SSR Markers. J Biodivers Biopros Dev 1: 126. doi:10.4172/2376-0214.1000126

Page 4 of 8

\begin{tabular}{|c|c|c|c|c|}
\hline & F: CCATTTCAGACACATCAAGTAAC & & & \\
\hline PdCAT2O & R: GGATATAAGTAGCTAACCCGAACC & (GA)29 & 219 & 53 \\
\hline
\end{tabular}

Table 2: Characteristics of 18 used microsatellite primers.

\section{Analysis of SSR data}

The targeted fragments and allele scoring were performed by the ALFwin Fragment Analyser Software. For each marker, the average number of alleles per locus, the expected heterozygosity $(\mathrm{He})$ and the observed heterozygosity (Ho) were calculated by GenAlex 6.3 software. The fixation index or F-statistic (Fis, Fst) were computed according to Wright [40]. Values of FST (fixation index) ranged from 0 (completely undifferentiated) to 1 (completely differentiated). The genetic similarity and the analysis of molecular variance (AMOVA) were also calculated using GenAlex 6.3 software [41]. DARwin 5.0 software was used to make dendrograms which showed the distribution of different individuals.

\section{Results}

\section{Microsatellite amplification}

Among the 18 microsatellite makers used, 15 showed a net amplification of DNA fragments. MPdCIR044, MPdCIR048 and MPdCIR063 primers amplified only a few or no samples. In addition, these amplifications showed no polymorphism. Therefore, these three loci were not considered in the following statistical analyses.

Figure 2 represents an example of polyacrylamide gel showing the pattern of DNA fragments amplified with MPdCIR25 marker. The different sizes of the DNA fragments amplified, showed the polymorphism of the markers. This polymorphism is used for the determination of differences between samples and to calculate the genetic parameters.

\section{genetic parameters.}

\begin{tabular}{|l|l|l|l|l|l|l|l|l|l|l|l|l|l|l|l|}
\hline Primers & Pd10 & Pd15 & Pd16 & Pd25 & Pd32 & Pd35 & Pd50 & Pd57 & Pd70 & Pd78 & Pd85 & Pd90 & Pd93 & AT01 & AT20 \\
\hline Allele number & 8 & 7 & 5 & 6 & 11 & 4 & 11 & 6 & 10 & 11 & 10 & 6 & 5 & 8 & 8 \\
\hline
\end{tabular}

Table 3: Allele number per primer of Moroccan cultivars calculated with GenAlex 6.3 software Pd10: MPdCIR010; Pd15: MPdCIR015; Pd16: MPdCIR016; Pd25: MPdCIR025; Pd32: MPdCIR032; Pd35: MPdCIR035; Pd50: MPdCIR050; Pd57: MPdCIR057; Pd70: MPdCIR070; Pd78: MPdCIR078; Pd85: MPdCIR085; Pd90: MPdCIR090; Pd93: MPdCIR093; AT 01: PdCAT01; AT20: PdCAT20.

The percentage of polymorphic loci per cultivar varied between $60 \%$ and $100 \%$ with an average of $93.33 \%$ (Table 4 ).

\begin{tabular}{|l|l|}
\hline Cultivars & Percentage (\%) \\
\hline Assiane & 80,00 \\
\hline Boufeggous (Figuig) & 100,00 \\
\hline Tgharas & 86,67 \\
\hline Aziza bouzid & 100,00 \\
\hline Aziza manzou & 100,00 \\
\hline Boufeggous gharas & 100,00 \\
\hline Taâbdount & 93,33 \\
\hline Boufeggous (Zagora) & 100,00 \\
\hline
\end{tabular}

\begin{tabular}{|l|l|}
\hline Jihel (Zagora) & 93,33 \\
\hline Tadmant (Zagora) & 93,33 \\
\hline Afroukh & 100,00 \\
\hline Aguelid & 60,00 \\
\hline Mâles (Figuig) & 100,00 \\
\hline Boufeggous (Tata) & 100,00 \\
\hline Jihel (Tata) & 93,33 \\
\hline Admam (Figuig) & 100,00 \\
\hline Mejhoul & 93,33 \\
\hline Tadmant (Figuig) & 100,00 \\
\hline Mâles (Tata) & 93,33 \\
\hline
\end{tabular}


Citation: Bodian A, Nachtigall M, Frese L, Aziz Elhoumaizi M, Hasnaoui A, et al. (2014) Genetic Diversity Analysis of Date Palm (Phoenix dactylifera L.) Cultivars from Morocco Using SSR Markers. J Biodivers Biopros Dev 1: 126. doi:10.4172/2376-0214.1000126

Page 5 of 8

\begin{tabular}{|l|l|}
\hline Admam (Tata) & 80,00 \\
\hline Mean & 93,33 \\
\hline
\end{tabular}

Table 4: Percentage of polymorphic loci of Moroccan cultivars calculated with GenAlex 6.3 software.

\section{Heterozygosity and fixation index}

The total rate of heterozygosity $(\mathrm{Ht})$ by primer for all cultivars was very high and varied between 0.696 (MPdCIR93) and 0.945
(PdCAT20) (Table 5). The average of expected heterozygosity (MHe) ranged between 0.464 (MPdCIR16) and 0.677 (PdCAT20) and the average of observed heterozygosity ( $\mathrm{MHo}$ ) ranged between 0.816 (MPdCIR78) and 0.950 (PdCAT20) (Table 5). For all the markers, the observed heterozygosity value was higher than the expected one. The Fis values were negative for all markers and varied between -0.895 (MPdCIR32) and -0.404 (PdCAT20) per marker with an average of -0.757 (Table 5). The Fst values for their part varied between 0.267 (MPdCIR93) and 0.472 (MPdCIR78) with an average of 0.363 (Table $5)$.

\begin{tabular}{|l|l|l|l|l|l|l|l|l|l|l|l|l|l|l|l|l|}
\hline & Pd10 & Pd 15 & Pd 16 & Pd 25 & Pd 32 & Pd 35 & Pd 50 & Pd 57 & Pd 70 & Pd 78 & Pd 85 & Pd 90 & Pd 93 & AT01 & AT20 & Mean \\
\hline Ht & 0.800 & 0.736 & 0.736 & 0.798 & 0.718 & 0.811 & 0.847 & 0.819 & 0.828 & 0.906 & 0.853 & 0.831 & 0.696 & 0.850 & 0.945 & \\
\hline MHe & 0.516 & 0.512 & 0.464 & 0.518 & 0.517 & 0.524 & 0.541 & 0.491 & 0.478 & 0.479 & 0.506 & 0.512 & 0.510 & 0.484 & 0.677 & \\
\hline MHo & 0.913 & 0.898 & 0.822 & 0.935 & 0.980 & 0.950 & 1.000 & 0.856 & 0.846 & 0.816 & 0.907 & 0.844 & 0.902 & 0.900 & 0.950 & \\
\hline Fis & -0.769 & -0.755 & -0.772 & -0.805 & -0.895 & -0.813 & -0.849 & -0.744 & -0.772 & -0.706 & -0.790 & -0.649 & -0.767 & -0.861 & -0.404 & -0.757 \\
\hline Fst & 0.355 & 0.305 & 0.370 & 0.350 & 0.280 & 0.354 & 0.361 & 0.401 & 0.423 & 0.472 & 0.406 & 0.384 & 0.267 & 0.431 & 0.284 & 0.363 \\
\hline
\end{tabular}

Table 5: Heterozygoty and fixation index of Moroccan cultivars calculated with GenAlex 6.3 software Ht: total rate of heterozygosity; MHe: average of expected heterozygosity; MHo: average of observed heterozygosity; Fis: fixation index of individuals relative to subpopulations; Fst: fixation index of subpopulations compared to the total population.

\section{Genetic similarity}

Table 6 showed the degree of similarity between cultivars. The genetic similarity values ranged from 0.146 to 0.745 . The highest similarity value was observed between "Boufeggous" et "Boufeggous gharas" while "Aguelid" and "Mejhoul" had the smallest similarity value. "Mejhoul" and "Boufeggous" had also a high genetic similarity (0.702).

\begin{tabular}{|c|c|c|c|c|c|c|c|c|c|c|c|c|c|c|}
\hline Bfgs & Assia & Tghar & Azi b & Azi m & Jihel & Tadm & Bf gh & Taâb & Afr $n t$ & Aguel & Mâles & Adm & Mejh & \\
\hline 1.000 & & & & & & & & & & & & & & Bfgs \\
\hline 0.226 & 1.000 & & & & & & & & & & & & & Assia \\
\hline 0.636 & 0.549 & 1.000 & & & & & & & & & & & & Tghar \\
\hline 0.324 & 0.428 & 0.461 & 1.000 & & & & & & & & & & & Azi b \\
\hline 0.283 & 0.372 & 0.507 & 0.489 & 1.000 & & & & & & & & & & Azi $m$ \\
\hline 0.380 & 0.335 & 0.380 & 0.578 & 0.393 & 1.000 & & & & & & & & & Jihel \\
\hline 0.544 & 0.440 & 0.700 & 0.309 & 0.357 & 0.416 & 1.000 & & & & & & & & Tadm \\
\hline 0.745 & 0.395 & 0.649 & 0.417 & 0.386 & 0.306 & 0.495 & 1.000 & & & & & & & $\mathrm{Bf} g \mathrm{gh}$ \\
\hline 0.410 & 0.317 & 0.397 & 0.262 & 0.280 & 0.264 & 0.403 & 0.476 & 1.000 & & & & & & Taâb \\
\hline 0.482 & 0.573 & 0.580 & 0.465 & 0.531 & 0.429 & 0.553 & 0.524 & 0.353 & 1.000 & & & & & Afr nt \\
\hline 0.184 & 0.238 & 0.392 & 0.310 & 0.187 & 0.211 & 0.246 & 0.172 & 0.275 & 0.244 & 1.000 & & & & Aguel \\
\hline 0.486 & 0.590 & 0.680 & 0.417 & 0.437 & 0.427 & 0.572 & 0.566 & 0.359 & 0.585 & 0.331 & 1.000 & & & Mâles \\
\hline 0.522 & 0.590 & 0.629 & 0.616 & 0.498 & 0.481 & 0.527 & 0.624 & 0.472 & 0.686 & 0.485 & 0.656 & 1.000 & & Adm \\
\hline 0.702 & 0.309 & 0.555 & 0.233 & 0.205 & 0.360 & 0.619 & 0.531 & 0.293 & 0.476 & 0.146 & 0.457 & 0.503 & 1.000 & Mejh \\
\hline
\end{tabular}

Table 6: Genetic similarity between Moroccan cultivars calculated with GenAlex 6.3 software Bfgs: Boufeggous; Assia: Assiane; Tghar: Tgharas; Azi b: Aziza bouzid; Azi m: Aziza manzou; Tadm: Tadmant; Bf gh: Boufeggous gharas; Taâb: Taâbdount; Afr nt: Afroukh n’tijent; Aguel: Aguelid; Adm: Admam; Mejh: Mejhoul. 
Citation: Bodian A, Nachtigall M, Frese L, Aziz Elhoumaizi M, Hasnaoui A, et al. (2014) Genetic Diversity Analysis of Date Palm (Phoenix dactylifera L.) Cultivars from Morocco Using SSR Markers. J Biodivers Biopros Dev 1: 126. doi:10.4172/2376-0214.1000126

Page 6 of 8

\section{Analysis of molecular variance between Moroccan cultivars}

Molecular variance analysis showed $64 \%$ of variability among Moroccan cultivars (Figure 3).

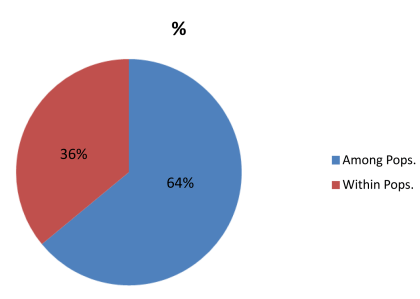

Figure 3: Analysis of molecular variance between Moroccan cultivars.

\section{Dendrogram of similarity of moroccan cultivars}

The similarity dendrogram (Figure 4 ) showed 3 main groups ( $a, b$ and c). The first group (c) was divided into 2 subgroups (one subgroup constituted by 2 individuals of "Aziza manzou", 1 individual of "Boufeggous" from Figuig, 6 individuals of "Tgharas", and 2 males from Figuig and one subgroup constituted by the rest of "Tgharas" individuals). The second group (b) was divided into 2 subgroups also. The first subgroup was constituted by individuals of "Boufeggous" from Zagora and from Tata, 1 individual of "Boufeggous" from Figuig, 2 individuals of "Mejhoul", 1 "Admam", 1 "Tadmant" from Figuig, 2 "Boufeggous gharas" and 2 "Ahardane". The second subgroup was constituted by 1 "Admam" and 1 "Tadmant" from Figuig. The third group (a) was also divided into 2 subgroups. The first one was constituted by the 5 individuals of "Tadmant" from Zagora, the 5 males from Figuig remaining and the 2 males from Tata. The second one was constituted by the individuals of "Aguelid", 2 "Taâbdount", 2 "Admam", "Jihel" individuals and by the rest of samples.

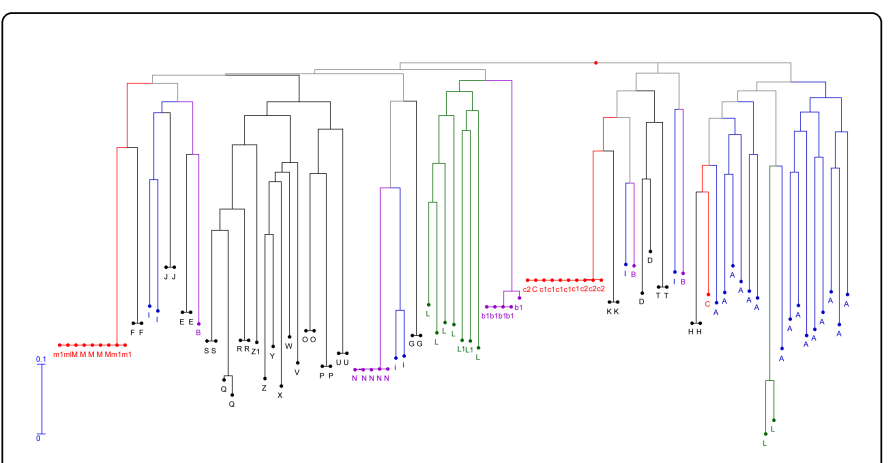

Figure 4: Dendrogram of genetic similarity of Moroccan cultivars.
A: Tgharas
B: Tadmant (Figuig)
C: Boufeggous (Figuig)
D: Boufeggous gharas (Figuig) E: Assiane
F: Aziza bouzid
G: Taâbdount
$\mathrm{H}$ : Aziza manzou
I: Admam,
J: Afroukh n'tijent
K: Mejhoul
L: Mâles (Figuig)
b1: Tadmant (Zagora)
c1: Boufeggous (Zagora) M: Jihel2
$\mathrm{N}$ : Aguelid
O: Oum nehl
P: Iklane

Q: Bousthammie noire

R: Bouzgagh

S: Meh Albayed

$\mathrm{T}$ : Ahardane

c2: Boufeggous (Tata) m1: Jihel1 (Tata)

i: Adamam (Tata)

U: Bouskri

V: Bouhassa

W: Bouyatoub

$\mathrm{X}$ : Sayer layalat

Y: Amanane

Z: Taghamint

Z1: Tiguemi n'tanount

L1: Mâles (Tata)

\section{Discussion}

MPdCIR044, MPdCIR048 and MPdCIR063 markers had a low or a lack of amplification of DNA samples. Similar observations have been reported by Zehdi et al. [18]; Billotte et al. [37] and Bodian et al. $[23,24]$ for the first two markers.

The number of alleles found per locus ranging from 4 to 11 is the same as that found by Bodian et al. [24] who used the cultivars of Figuig only with the same markers. It is comparable to that found by Zehdi et al. [18] (ranging between 4 and 10) who recognized 7.14 alleles per locus when examining 46 Tunisian date palm accessions using 14 microsatellite loci. It is also comparable to Elmeer et al. [22] results who found between 4 and 12 alleles per locus. However it is lower to that found by Billotte et al. [37] (ranging between 5 and 18) and it is very high compared to Ahmed and Al-Qaradawi [42] studies who marked 40 different alleles with a mean of 4 alleles per locus by examining 15 Qatari date palm cultivars.

An excess of heterozygosity manifested by negative Fis values was observed. The average value of Fst equal to 0.363 means that the index of genetic differentiation was very high among all cultivars. This result is obtained by Bodian et al. [24] when examined only Figuig cultivars.

Statistical analysis showed that the genetic similarities between cultivars are fairly variable (ranging from 0.146 to 0.745 ). These values suggest that there are cultivars that are genetically very close and others that are very far. These genetic similarities are comparable to those found by Ahmed and Al-Qaradawi [42] (ranging between 0.00 and 0.75 ) and by Zehdi et al. [18] (ranging between 0.3008 and 0.7885 ) and by Bodian et al. [24]. The highest similarity value observed between "Boufeggous" and "Boufeggous gharas" means that they are genetically the closest. While Aguelid and Mejhoul had the smallest similarity value, that means they are the most genetically distant. "Mejhoul" and "Boufeggous" have also a high genetic similarity (0.702).

The analysis of molecular variance (64\% of variability among cultivars), the average value of Fst and the values of genetic similarity suggest a variable polymorphism among Moroccan cultivars.

The dendrogram showed that "Jihel" individuals of Tata and those of Zagora were in the same subgroup and in the same level. So this cultivar was the same of one oasis to another and individuals did not show any genetic variability. This was the case of "Boufeggous" individuals of Figuig, Tata and Zagora. So "Jihel" of Tata was the same that "Jihel" of Zagora and "Boufeggous" of Figuig was also the same that "Boufeggous" of Tata and Zagora. However "Tadmant" individuals of Figuig were not in the same group with those of Zagora. Moreover, "Tadmant" individuals of Figuig showed variability while those of Zagora were identical. That could mean that "Tadmant" of Figuig was different that "Tadmant" of Zagora. They were two cultivars which had the same name but were genetically different: they could be homonyms. 
Citation: Bodian A, Nachtigall M, Frese L, Aziz Elhoumaizi M, Hasnaoui A, et al. (2014) Genetic Diversity Analysis of Date Palm (Phoenix dactylifera L.) Cultivars from Morocco Using SSR Markers. J Biodivers Biopros Dev 1: 126. doi:10.4172/2376-0214.1000126

Page 7 of 8

All males were in the same subgroup except two males from Figuig. Similar results were observed when Figuig cultivars only were analyzed [24]. Males from Tata and those from Figuig were in the same subgroup. Males were not clustered according to their geographical origin.

This study revealed the existence of genetic variation among Moroccan cultivars. So genetic differentiation was high and an excess of heterozygosity was observed. In general, cultivars were identical from one oasis to another ("Boufeggous", "Jihel"). But, one case of homonymy was noticed. In fact "Tadmant" of Figuig was genetically different from "Tadmant" of Tata and Zagora.

\section{Acknowledgment}

This work was the result of collaboration between Mohamed 1st university of Oujda (Morocco), university Cheikh Anta Diop of Dakar (Senegal), university of Thiès (Senegal) and Julius Kühn-Institut (JKI): Institute for Breeding Research on Agricultural Crops in Quedlinburg (Germany). Thanks are due to providing facilities and excellent support of the experiments. We are grateful to Dr. Lothar Frese and Dr. Marion Nachtigall for collaboration and advices.

\section{References}

1. Barrow S (1998) A monograph of Phoenix L. (Palmae: Coryphoideae). Kew Bull 53: 513-575.

2. Malek JA (2010) Next generation DNA sequencing applied to the Date palm tree (Phoenix dactylifera). Acta Hortic 882: 249-252.

3. Toutain G, Bachra A Et Chari A (1971) Cartographie variétale de la palmeraie marocaine. Direc Rech Agron, Rabat. Morocco: 242.

4. Pereau-Leroy $P$ (1958) Le palmier dattier au Maroc. Ministère de l'Agriculture. Instit Franc Rech Outre-mer, Paris : 142

5. Djerbi M (1989) Compte rendu du 2ème Séminaire Maghrébin sur la multiplication rapide du palmier dattier par. les techniques de culture in vitro: 5-7.

6. El Houmaizi MA, Saaidi M, Oihabi A and Cilas C (2002) Phenotypic diversity of date-palm cultivars (Phoenix dactylifera L.) from Morocco. Genetic Resources and Crop Evolution 49: 483-490.

7. Salem AOM, Rouma S, Zehdi S, Marrakchi M and Trifi M (2008) Morphological variability of Mauritanian date palm (Phoenix dactylifera L.) cultivars revealed by vegetative traits. Acta Bot. Croat 67: 81-90.

8. Baaziz M and Saaidi M (1988) Preliminary identification of date palm cultivars by esterase isoenzymes and peroxidases activities. Can J Bot 66: 89-93.

9. Salem AOM, Trifi M, Rhouma A and Marrakchi M (2001) Genetic inheritance analyses of four enzymes in date palm (Phoenix dactylifera L.). Genet. Resour. Crop Evol 48: 361-368.

10. Majourhat K, Medraoui KBL and Baaziz M (2002) Diversity of leaf peroxidases in date palm (Phoenix dactylifera L.) as revealed in an example of marginal (seedling derived) palm groves. Sci. Hort 95: 31-38.

11. Baaziz M, Bendiab K, Brakez Z and Ait Chitt M (1993) Le polymorphisme enzymatique du palmier dattier (Phoenix dactylifera L.) utilisé comme marqueur de la conformité génétique des vitro-plants. In : Le progrès génétique passe-t-il par le repérage et l'inventaire des gènes ? AUPELF-UREF Ed. John Libbey Eurotext, Paris: 155-158.

12. Aitchitt M, Mantell S, Thangavelu M and Ainsworth C (1995) Cloning date palm (Phoenix dactylifera L.) DNA and characterization of low, medium and high copy DNA sequences. Elaeis 7: 57-63.

13. Sedra $\mathrm{MyH}$, Lashermes P, Trouslot P, Combes M and Hamon S (1998) Identification and genetic diversity analysis of date palm (Phoenix dactylifera L.) varieties of Morocco using RAPD markers. Euphytica 103: 75-82.
14. Abdulla M and Gamal O (2010) Investigation on molecular phylogeny of some date palm (Phoenix dactylifra L.) cultivars by protein, RAPD and ISSR markers in Saudi Arabia. Aust. J Crop Sci 4: 23-28.

15. Rhouma CS, Baraket G, Dakhlaoui DS, Zehdi AS and Trifi M (2011) Molecular research on the genetic diversity of Tunisian date palm (Phoenix dactylifera L.) using the random amplified microsatellite polymorphism (RAMPO) and amplified fragment length polymorphism (AFLP) methods. African Journal of Biotechnology 10: 10352-10365.

16. Al-Khalifah NS, Askari E (2003) Molecular phylogeny of date palm (Phoenix dactylifera L.) cultivars from Saudi Arabia by DNA fingerprinting. Theor Appl Genet 107: 1266-1270.

17. Soliman SS, Ali BA and Ahmed MM (2003) Genetic comparisons of Egyptian date palm cultivars (Phoenix dactylifera L.) by RAPD-PCR. Afr. J. Biotechnol 2: 86-87.

18. Zehdi S, Trifi M, Billotte N, Marrakchi M, Pintaud JC (2004) Genetic diversity of Tunisian date palms (Phoenixdactylifera L.) revealed by nuclear microsatellite polymprohism. Hereditas 141: 278-287.

19. Zehdi S, Sakka H, Rhouma A, Salem AOM, Marrakchi M, et al. (2004b) Analysis of Tunisian date palm germplasm using simple sequence repeat primers. Afr J Biotechnol 3: 215-219.

20. Rawashdeh I and Amri A (2006) Genetic characterization of date palm varieties using RAPD markers. Jordan J. Agri. Sci 2: 234-242.

21. Elshibli S, Korpelainen H (2008) Microsatellite markers reveal high genetic diversity in date palm (Phoenix dactylifera L.) germplasm from Sudan. Genetica 134: 251-260.

22. Elmeer K, Sarwath H, Malek J, Baum M, Hamwieh A (2011) New microsatellite markers for assessment of genetic diversity in date palm (Phoenix dactylifera L.). 3 Biotech 1: 91-97.

23. Bodian A, Ndoye-Ndir K, Diédhiou PM, Borgel A, Sané D, et al. (2012a) Analysis of genetic diversity of date palm (Phoenix dactylifera L.) cultivars from Mauritania using microsatellite markers. International Journal of Science and Advanced Technology 2: 36-43.

24. Bodian A, El Houmazi MA, Ndoye-Ndir K., Hasnaoui A, Nachtigall M, et al. (2012b) Genetic diversity analysis of date palm (Phoenix dactylifera L.) cultivars from Figuig oasis (Morocco) using SSR markers. International Journal of Science and Advanced Technology 2: 96-104.

25. Hancock JM (1997) Microsatellites and other simple sequences: genomic context and mutational mechanisms. Oxford University Press: 1-9.

26. Liu ZW, Biyashev RM, Maroof MA (1996) Development of simple sequence repeat DNA markers and their integration into a barley linkage map. Theor Appl Genet 93: 869-876.

27. Taramino G, Tingey S (1996) Simple sequence repeats for germplasm analysis and mapping in maize. Genome 39: 277-287.

28. Röder MS, Korzun V, Wendehake K, Plaschke J, Tixier MH, et al. (1998) A microsatellite map of wheat. Genetics 149: 2007-2023.

29. Santoni S, Faivre-Rampant P, Prado E et Prat D (2000) Ressources génétiques : Marqueurs moléculaires pour l'analyse des ressources génétiques et l'amélioration des plantes. Cahiers d'Agriculture 9: 311327.

30. Tautz D, Renz M (1984) Simple sequences are ubiquitous repetitive components of eukaryotic genomes. Nucleic Acids Res 12: 4127-4138.

31. Goodfellow PN (1992) Human genome project. Variation is now the theme. Nature 359: 777-778.

32. Field D, Wills C (1996) Long, polymorphic microsatellites in simple organisms. Proc Biol Sci 263: 209-215.

33. Condit R, Hubbell SP (1991) Abundance and DNA sequence of two-base repeat regions in tropical tree genomes. Genome 34: 66-71.

34. Röder MS, Plaschke J, König SU, Börner A, Sorrells ME, et al. (1995) Abundance, variability and chromosomal location of microsatellites in wheat. Mol Gen Genet 246: 327-333.

35. Schug MD, Hutter CM, Wetterstrand KA, Gaudette MS, Mackay TF, et al. (1998) The mutation rates of di-, tri- and tetranucleotide repeats in Drosophila melanogaster. Mol Biol Evol 15: 1751-1760. 
Citation: Bodian A, Nachtigall M, Frese L, Aziz Elhoumaizi M, Hasnaoui A, et al. (2014) Genetic Diversity Analysis of Date Palm (Phoenix dactylifera L.) Cultivars from Morocco Using SSR Markers. J Biodivers Biopros Dev 1: 126. doi:10.4172/2376-0214.1000126

Page 8 of 8

36. Bousquet J, Simon L and Lalonde M (1990) DNA amplification from vegetative and sexual tissues of trees using polymerase chain reaction. Can J Forest Res 20: 254-257.

37. Billotte N, Marseillac N, Brottier P, Noyer J.L, Jacquemoud-Collet JP, et al. (2004) Nuclear microsatellite markers for the date palm (Phoenix dactylifera L.): characterization, utility across the genus Phoenix and in other palm genera. Mol. Ecol. Notes 4: 256-258.

38. Akkak A, Scariot V, Torello Marinoni D, Boccacci P, Beltramo C, et al. (2009) Development and evaluation of microsatellite markers in Phoenix dactylifera L. and their transferability to other Phoenix species. Biologia Plantarum 53: 164-166.
39. Schuelke M (2000) An economic method for the fluorescent labeling of PCR fragments. Nat Biotechnol 18: 233-234.

40. Wright S (1965) The interpretation of population structure by F-statistics with special regard to systems of mating. Evolution 19: 395-420.

41. Peakall R, Smouse PE (2012) GenAlEx 6.5: genetic analysis in Excel. Population genetic software for teaching and research--an update. Bioinformatics 28: 2537-2539.

42. Ahmed TA and Al-Qaradawi A (2009) Molecular phylogeny of Qatari date palm genotypes using simple sequence repeats markers. Biotechnology 8: 126-131. 